\title{
МОДЕРНІЗАЦІЯ КРАЕЗНАВЧОЇ ПІДГОТОВКИ МАЙБУТНІХ УЧИТЕЛІВ ГЕОГРАФІЇ
}

\begin{abstract}
Статтю присвячено проблемі модернізаиії краєзнавчої підготовки студентів-географів педагогічних ВНЗ. Автором розглянуто методику формування готовності майбутніх учителів географії до краєзнавчої роботи з учнями.

Ключові слова: краєзнавча робота, готовність до краєзнавчої роботи, модернізачія, методика формування готовності до краєзнавчої роботи.
\end{abstract}

Статья посвящена проблеме модернизации краеведческой подготовки студентов-географов педагогических вузов. Автором рассматривается методика формирования готовности будущих учителей географии к краеведческой работе с учащимися.

Ключевые слова: краеведческая работа, готовность к краеведческой работе, модернизаџия, методика формирования готовности к краеведческой работе.

The article deals with the problem of modernization of country study training of students geographers of pedagogical higher educational establishments. The author considers the methodology of forming of future geography teachers' readiness for country study work with pupils.

Key words: country study work, readiness for country study work, modernization, methodology of forming of readiness for country study work.

У нормативних документах, які визначають стратегію та основні напрямки функціонування освіти, зокрема в Державній національній програмі «Освіта» («Україна XXI ст.») та «Концепції національного виховання» зазначається, що український народ вступив до нової епохи свого історичного розвитку, яка характеризується інтеграцією та глобалізацією світових соціальних, економічних і культурних процесів. Тому перспективи розвитку української держави вимагають випереджувального оновлення завдань і змісту вищої освіти, з тим, щоб вона змогла стати гідним членом європейської освітньої спільноти. Модернізація вищої школи повинна задовольнити соціальну потребу в якісній освіті, а тому питання вдосконалення підготовки майбутніх фахівців до професійної діяльності набуває особливої гостроти. Повною мірою це стосується й підготовки вчителів.

Під час інтегрування вітчизняної освіти до міжнародного освітнього простору важливо зберегти іiі національний характер, сприяти збереженню культурної спадщини, формуванню в учнів національної самосвідомості через любов до рідного краю, патріотизм, без яких неможливий розвиток жодної нації. У зв'язку з цим важливого значення набуває краєзнавча підготовка студентів і формування в них готовності до краєзнавчої роботи з учнями.

Аналіз наукової літератури свідчить, що окремі аспекти досліджуваної проблеми знайшли висвітлення в працях, присвячених професійній підготовці майбутніх учителів, яка завжди перебувала в центрі уваги вчених. Питання вдосконалення загальнопедагогічної підготовки студентів в умовах вищого навчального закладу розглядали О. Абдулліна, Н. Кічук, Н. Кузьміна, Н. Ничкало, М. Ярмаченко. Дослідженням готовності студентів до різних видів педагогічної діяльності займалися такі вчені, як Г. Драндров, К. Дурай-Новакова, А. Міщенко, А. Капська, А. Ліненко, А. Серих, Г. Штельмах.

Вагомий внесок у теорію та практику підготовки майбутніх учителів саме до краєзнавчої роботи 3 учнями зробили В. Бенедюк， Т. Вайда， Т. Міщенко, С. Совгіра， М. Соловей， О. Тімець. Проблемі краєзнавчої освіти студентської молоді присвячено праці В. Обозного.

Між тим, аналіз наукових досліджень дає змогу говорити не лише про суттєві досягнення в осмисленні сутності та змісту готовності майбутніх учителів до професійної діяльності, але й про певні прогалини, що стосуються деяких важливих іiі аспектів. Так, готовність студентів географічних факультетів педагогічних університетів до краєзнавчої роботи з учнями не знайшла всебічного висвітлення в науковій літературі.

Аналіз стану досліджуваної проблеми в педагогічній теорії та практиці доводить, що існує суперечність між об’єктивно зростаючими суспільними потребами в краєзнавчій підготовці майбутніх учителів і недостатньою розробленістю теоретичних основ формування готовності студентів географічних факультетів до краєзнавчої роботи з учнями. Подолання цієї суперечності передбачає пошук оптимальних шляхів удосконалення підготовки студентів географічних факультетів.

Mema cmammi полягає у висвітленні методики формування готовності майбутніх учителів географії до краєзнавчої роботи з учнями.

Краєзнавча підготовка майбутніх учителів відіграє важливу роль у предметній підготовці за спеціальністю «географія» в педагогічних ВНЗ, оскільки формування творчого ставлення до використання краєзнавчих знань у подальшій професійній діяльності потребує розв'язання конкретних практичних завдань у географічній освіті.

На думку К. Строєва, краєзнавча підготовка студентів у навчальному процесі педагогічного вишу - це всебічне вивчення студентами рідного краю під час засвоєння навчальних курсів; збирання, 
накопичення й систематизація польових матеріалів, які сприяють чіткому розкриттю та розумінню взаємозв’язків у природі та суспільстві, що забезпечує формування науково-методичних навичок для роботи в умовах школи [1].

Аналіз нормативних документів географічних факультетів у педагогічних ВН3, спостереження за студентами під час навчального процесу свідчать про те, що підготовка майбутніх учителів географії до вивчення рідного краю потребує модернізації: у 22 \% студентів низький рівень теоретичних знань, у $58 \%$ - практичні вміння сформовані на низькому рівні, в інших студентів відсутнє бажання здійснювати краєзнавчу роботу в загальноосвітніх закладах.

С. Литвиненко слушно зазначає, що «підготовка виступає засобом формування готовності до діяльності, а готовність є результатом і показником якості підготовки, що реалізується й перевіряється в діяльності» [2, с. 157]. Тому під краєзнавчою підготовкою слід розуміти динамічний процес, кінцевою метою якого є формування готовності до краєзнавчої роботи.

Аналіз наукової літератури дає змогу говорити про відсутність єдиної позиції щодо визначення сутності понять «готовність», «готовність до краєзнавчої роботи». Готовність у психолого-педагогічних дослідженнях трактується по-різному: як психологічна настанова (Д. Прангішвілі, Д. Узнадзе), багаторівнева структура рис, властивостей і станів особистості, які в сукупності дозволяють їй успішно здійснювати професійну діяльність (М. Дьяченко, Л. Кандибович, В. Крутецький, С. Максименко, В. Моляко, О. Пелех, А. Щербаков), певний функціональний стан (А. Ковальов, М. Левітов), особливий психічний стан (В. Сластьонін, О. Мороз), складне особистісне утворення (Г. Штельмах), вибіркова активність, що налаштовує особистість на майбутню діяльність (А. Ліненко).

Готовність студентів-географів до краєзнавчої роботи 3 учнями як складова більш загального поняття «готовність учителя до педагогічної діяльності» $є$ складним особистісним утворенням, що охоплює краєзнавчу спрямованість, позитивну мотивацію, професійно важливі риси особистості, краєзнавчі знання, вміння й навички, оцінку, адекватну самооцінку та рефлексію результатів власної праці, забезпечуючи ефективність краєзнавчої роботи. Тому структура зазначеного особистісного утворення об'єднує такі складові компоненти: ціле-мотиваційний, який виконує спонукальну функцію; змістово-операційний, що виконує інформаційну й трансляційну функції; емоційновольовий, який виконує орієнтаційну й регулятивну функцію, та оцінно-рефлексивний, що виконує експертну функцію.

Під час дослідження ми дійшли висновку, що процес формування готовності студентів-географів до краєзнавчої роботи з учнями буде успішним, якщо під час організації та здійснення навчального процесу й педагогічної практики цілям підготовки до краєзнавчої роботи надаватиметься особистісний смисл $\mathrm{i}$ забезпечуватиметься позитивна мотивація студентів в оволодінні узагальненими краєзнавчими знаннями й уміннями використовувати їх при розв'язанні проблемних ситуацій і пізнавальних задач; активізуватиметься діяльність студентів на основі особистісно зорієнтованого й імітаційно-ігрового підходів до організації краєзнавчої підготовки в умовах вищого навчального закладу; урізноманітнюватимуться форми й методи краєзнавчої роботи 3 наданням майбутнім педагогам свободи вибору способів розв'язання навчальних проблем і забезпеченням ситуацій успіху.

Розглянемо методику формування означеної готовності, яка має поетапний характер.

На першому (організаційно-орієнтаційному) етапі основне завдання дослідження полягало у формуванні ціле-мотиваційного компонента готовності до краєзнавчої роботи через забезпечення та експериментальну перевірку педагогічних умов, що стимулюють позитивну мотивацію навчання, забезпечують усвідомлення цілей підготовки до краєзнавчої роботи й надання їм особистісного смислу, соціальної значущості краєзнавчої роботи в процесі формування особистості учнів і власного професійного становлення, формування краєзнавчої спрямованості діяльності студентів.

Названі педагогічні умови реалізувалися під час організації навчального процесу та ознайомлювальної педагогічної практики, під час якої в майбутніх учителів формувалося уявлення про систему краєзнавчої роботи в школах міста, іiі цілі, завдання, основні напрямки та форми. Увага приділялася висвітленню психолого-педагогічних особливостей шкільного краєзнавства, демонструванню навчально-виховних можливостей краєзнавчої роботи в усебічному гармонійному розвитку особистості учня, а також вирішальної ролі вчителя в їх успішній реалізації. Перевага надавалася порівняльному аналізу теоретичних положень і стану проблеми в практиці сучасної загальноосвітньої школи, що у своїй сукупності сприяло формуванню позитивної мотивації студентів. Із цією ж метою практикувалося написання студентами творів-мініатюр краєзнавчої тематики, розв'язувалися завдання 3 виявлення рівня організації краєзнавчої роботи в школі, визначення ступеня готовності вчителів до окресленого аспекту педагогічної діяльності, 3'ясування рівня краєзнавчих знань учнів, вивчення та узагальнення передового педагогічного досвіду вчителів міських шкіл з організації краєзнавчої діяльності.

На другому (пізнавально-аналітичному) етапі з метою набуття професійно важливих знань, умінь $і$ навичок майбутніми вчителями, важлива роль відводилася розв'язанню різноманітних проблемних завдань краєзнавчого характеру, диспутам, діалогам, проблемним бесідам, підготовці творчих проектів, що вимагало інтелектуальної напруги та вияву самостійності студентів (під час вивчення 
першоджерел й архівних документів, дослідження природних і соціально-економічних особливостей краю, складання схем, карт, планів, оформлення результатів пошуково-дослідницької роботи).

Оволодіння майбутніми вчителями узагальненими краєзнавчими знаннями й уміннями використовувати їх при розв’язанні проблемних ситуацій і пізнавальних задач сприяло посиленню позитивної мотивації та ефективному формуванню змістовно-операційного компонента досліджуваної готовності.

На третьому (репродуктивно-конструктивному, або діяльнісному) етапі відбувалася реалізація такої педагогічної умови як активізація діяльності студентів на основі особистісно зорієнтованого та імітаційно-ігрового підходів, що сприяло гармонізації теоретичної, практичної та методичної підготовки до краєзнавчої роботи.

На цьому етапі формування готовності студентів географічних факультетів до краєзнавчої роботи 3 учнями здійснювалася в процесі вивчення спецкурсу «Організація краєзнавчої роботи в школі», завдання якого полягали у вихованні любові та інтересу до рідного краю, усвідомленні професійної значущості краєзнавчої роботи; засвоєнні майбутніми вчителями теоретичних основ шкільного краєзнавства; посиленні практико-орієнтованого спрямування підготовки студентів до краєзнавчої роботи з учнями різних вікових груп, оволодінні студентами методикою дослідження рідного краю; набутті професійно важливих особистісних рис шляхом проведення лекційних і лабораторних занять, виконання самостійних робіт і проходження польової та навчально-виробничої практики. Під час вивчення спецкурсу використовувалися різноманітні ділові ігри, підготовка творчих проектів, бесіди за круглим столом, семінари з розв'язання творчих завдань, дискусії.

Формування та закріплення краєзнавчих умінь (гностичних, організаційних, конструктивнодослідницьких, комунікативних) і навичок, відпрацювання різноманітних форм краєзнавчої роботи 3 учнями, становлення світоглядної позиції та позитивного ставлення до досліджуваного аспекту педагогічної діяльності відбувалося під час навчально-виробничої практики.

Поетапно розв'язувалися такі завдання: підготовка методичних розробок краєзнавчих заходів, планів-конспектів уроків, практичних занять на місцевості, факультативних занять, засідань краєзнавчого гуртка; складання планів краєзнавчої роботи для класу чи школи; розроблення маршрутів краєзнавчих стежок, екскурсій, походів; презентація результатів краєзнавчої діяльності, демонстрування фрагментів уроків та виховних заходів краєзнавчого спрямування.

Четвертий (пошуково-дослідницький) етап реалізувався в процесі переддипломної практики та через науково-дослідницьку діяльність. На цьому етапі формування досліджуваного особистісного утворення забезпечувалася та експериментально перевірялася така педагогічна умова, як урізноманітнення форм і методів краєзнавчої роботи з наданням майбутнім учителям свободи вибору способів розв'язання навчальних проблем і забезпеченням ситуацій успіху в оволодінні методикою вивчення рідного краю.

Протягом педагогічної практики відбувалося закріплення краєзнавчих умінь та навичок, реалізація творчого підходу до організації та проведення різних форм краєзнавчої діяльності з учнями, поглиблення уявлення про технології вивчення рідного краю, формування професійно важливих особистісних рис, активної професійної позиції випускників, уміння оцінити результати своєї праці та накреслити шляхи подальшого професійного саморозвитку.

На цьому етапі широкого використання набули розробка та проведення різноманітні за змістом та складністю краєзнавчі заходи, підготовка наукових робіт краєзнавчої тематики, участь у заходах, пов'язаних із природоохоронною, туристсько-краєзнавчою роботою (туристичні зльоти, краєзнавчі та природоохоронні форуми, екологічні акції). Актуалізації критичного ставлення майбутнього вчителя до процесу та результату своєї роботи сприяла реалізація таких форм, як «краєзнавчо-педагогічний волейбол», «коло ідей», «велике коло», «акваріум» тощо.

Багатоступеневість, багаторівневість підходу до підготовки сучасних педагогів визначають варіативність змісту: студенти-бакалаври зорієнтовані на засвоєння теоретичних основ і відпрацювання методики краєзнавчої роботи $з$ дітьми різних вікових категорій, а студенти-магістри повинні бути підготовлені до дослідницької діяльності у сфері краєзнавства, аналітичної, експертно-консультативної діяльності у сфері туристсько-краєзнавчої діяльності.

Можемо зробити висновок, що забезпечення на практиці згаданих механізмів реалізації педагогічних умов сприяє більш успішному протіканню процесу формування готовності студентів географічних факультетів педагогічних ВНЗ до краєзнавчої роботи з учнями.

Подальшого детального розгляду потребують питання вивчення можливостей професійного самовиховання у формуванні готовності до краєзнавчої роботи; пошук шляхів взаємодії школи та ВНЗ із метою підвищення професійної краєзнавчої підготовки вчителів та студентів.

\section{Література}

1. Строев К. Ф. Краеведение / Константин Федосеевич Строев. - М. : Просвещение, 1974. - 144 с. 2. Литвиненко С. А. Соціально-педагогічна підготовка майбутнього вчителя : [монографія] / Світлана Анатоліївна Литвиненко. - Одеса : СВД Черкасов М. П.; Рівне : РДГУ, 2004. - 302 с. 